\title{
EFFECT PLANT DENSITY AND POULTRY MANURE ON RAPID MULTIPLICATION OF A CASSAVA PROPAGULE
}

\author{
OKOLI, NNEKA ANGELA.; OBIEFUNA, JULIUS CHIEDOZIE.; IBEAWUCHI, \\ IZUCHUKWU AND ALAGBA, ROSEMOND ADAOHURU \\ Department of Crop Science and Technology \\ Federal University of Technology, P.M.B 1526 Owerri, Nigeria \\ Corresponding authour: amderealangel@yahoo.com,
}

\begin{abstract}
This study appraised the effect of plant density and poultry manure rates on rapid multiplication of a cassava propagule during the late cropping season of 2007. Nine (9) treatments consisting of three cassava densities $(1.0 \times 1.0,1.0 \times 0.5,1.0 \mathrm{~m} \times 0.25 \mathrm{~m})$ amended with three rates of poultry manure (0, 2 and 4 tons/ha) were laid out in $3 \times 3$ factorial arrangement in a randomized complete design with three replications. The research work was carried out at the Teaching and Research Farm, Federal University of Technology, Owerri in the humid rainforest of Southeastern Nigeria. Growth and yield data were collected and statistically analyzed. The soil fertility at planting was low. Poultry manure rates significantly improved the growth and yield of cassava. Cassavas spaced $1.0 \mathrm{~m} \times 0.25 \mathrm{~m}$ and amended with 4 tons/ha of poultry manure were significantly tall with moderate girth and highest stem bundles and root tuber yield. Regenerative stem cuttings had good field establishment vigour. Post-harvest soil chemical analysis showed improvement in nutrient status of the soil. Cassava spaced $1.0 \mathrm{~m} \times 0.25 \mathrm{~m}$ and amended with 4 tons/ha of poultry manure had highest benefit cost ratio.
\end{abstract}

Key words: plant density, poultry manure, cassava

\section{INTRODUCTION}

Cassava is a vegetatively propagated crop grown for food, raw materials for industries and most recently for export (Ustimenenko-Bakumosvsky, 1983; Mayhew and Penny, 1988 and Pierre, 1989). Various authors (Nweke, 1992; Akoroda et al. and Spencer et al., 1997) have described cassava as a cash crop. The demand for cassava roots is on the increase as influenced by demographic and market forces. Due to the obvious reasons (consumption, industrial raw materials and export), cassava is preferred to the extent that the demand for the propagating material (stem cutting) is not met with supply since cassava has multiplication ratio of 1:10 (Cock, 1985), which is low when compared to maize propagated through seed that has a multiplication ratio of 1:300. Additionally, cassava stems have short shelf life due to dehydration and microbial attack (Otoo, 1996 and Earrnet, 2002).

There is need to develop an alternative method to overcome the problem of low multiplication ratio in cassava. Literatures (Bhjowani and Razdan, 1996; George et al., 2008; Earrnet, 2002 and Otoo, 1996) have cited the use of tissue culture and ministems cuttings for rapid multiplication but these techniques have limitations. Tissue culture produces healthy new plants rapidly but it is beyond the reach of resource poor illiterate farmers since it requires technical expertise of trained a breeder and funds (Earrnet, 2010; Bhjowani and Razdan, 1996 and George et al., 2008). The use of ministems cuttings for rapid multiplication involves nursery practices which last for 4-6 weeks and as such increase the cost of production and extends the time of production (9 months) (Otto, 1996) and thus fails to meet the targeted next cropping season. The use of macrostems for late season rapid multiplication eliminates nursery production and ensuing cost of production and cassava stems are harvested 
at six months after planting to meet the market demand at the next cropping season (Dahniya and Kallon, 1984).

Enhancing increased cassava stem production, therefore, requires improved agronomic packages especially appropriate cassava population and manure packages which in this study addressed increasing poultry manure rates on a cassava population for increased yield. Poultry manure improves soil productivity in two ways namely; through the improvement in the physical conditions of the soil such as structure and tilth and secondly, through its nutrients supplies to crops. Jinadasa et al. (1997) have reported that poultry manure applications increased soil $\mathrm{pH}$, organic matter content, available phosphorus, exchangeable cations and micro nutrients and decreased soil salinity and extractable iron. Microbial activity in nutrient immobilization increased with soil organic matter (Tian et al., 1994) and decomposition (Giller et al., 1997). Adequate plant population increases yield in cassava by efficient use of solar energy and soil nutrients (Dahniya and Kallon, 1984 and Cock, 1977).

\section{MATERIALS AND METHODS}

The experiment was carried out at the Federal University of Technology, Owerri, Teaching and Research Farm located in the humid tropics of Nigeria. It lies between Latitude $5^{\circ} 27^{1} \mathrm{~N}$ and Longitude $7^{\circ} 02^{1} \mathrm{E}$ ). The annual rainfall is about $2500 \mathrm{~mm}$ and is bimodal with peaks in July and September (Nwosu and Adeniyi, 1980). The area is characterized by daily minimum and maximum temperatures $20^{\circ} \mathrm{C}$ and $32^{\circ} \mathrm{C}$ respectively. In terms of geology and geomorphology, the predominant parent material from which most of the soils are formed is the Coastal Plain Sands popularly known as "Acid Sands" (Orajaka, 1975) underlain the study area. Soils of the areas are classified as Isohyperthemic Arenic Kandiudult (Onweremadu et al., 2006).

\section{Field study}

The experiment was a 3 x 3 factorial in RCBD replicated three times. The treatments; poultry manure and plant density had three levels each. Poultry manure rates were 0,2 and 4 tons/ha. Plant densities were $1.0 \times 1.0,1.0 \times 0.5$ and $1.0 \mathrm{~m} \times 0.25 \mathrm{~m}$. This gave a total of nine (9) treatment combinations with 0 ton/ha and $1.0 \times 1.0 \mathrm{~m}$ as the control. Cassava stems NR 8082 were sourced from healthy and matured cassava plants at ADP field of Owerri. Cured poultry manure was sourced from University Teaching and Research Farm (Animal Production Section). Stakes of $25 \mathrm{~cm}$ long were planted inclined at the specified spacing on ridges in late September 2007 in a $4 \mathrm{~m}$ x $2 \mathrm{~m}$ plots, the next day after cutting from the field. Poultry manure was applied by side dressing one week after planting. The cassava stems were harvested 6 months after planting (MAP) and the generated stems were planted in the field for propagule vigour test at $1 \mathrm{MAP}$.

\section{Laboratory analysis}

Poultry manure was analyzed for its nutrient status using the same procedures in the soil analysis. Core soil samples were collected from the experimental site at $0-15 \mathrm{~cm}$ depth before ploughing and after harvesting. Samples were analysed for physio-chemical properties at the Crop Science Laboratory, Federal University of Technology, Owerri. Soil pH was analysed by the use of $\mathrm{pH}$ meter (Hendershot et al., 1993), organic matter values were obtained by multiplying total organic carbon with 1.724 (Van Bemmelen's correlation factor) (Nelson and Sommers, 1982), available phosphorus according to the procedure of Olson and Sommers (1990), total nitrogen by microkjeldahl digestion technique (Bremner, 1996), calcium and magnesium by Versnate titration method and potassium by flame photometer method. 


\section{Data collection}

The following parameters were measured on the five randomly selected cassava plants in the central row at 1, 3 and 6 months after planting (MAP): Number of days to 50\% sprouting; number of sprouts; number of aborted sprouts; number of leaves; leaf area index; cassava height; cassava girth; number of nodes; stem bundles per hectare; stem weight per plot; dry weight of plantlets.

\section{Data analysis}

Results were analyzed using statistical software, Genstat 2000 and interpretation of data was based on Wahua (1999). Least Significant Difference was used to test and separate the means.

\section{RESULTS AND DISCUSSION}

Pre-planting soil analysis (Table 1) indicated that apart from the acidic nature of the soil, its nutrient status is low. This agreed with Ohiri and Ano (1985) who reported that soils in Imo, Abia and Akwa Ibom belong to the group characterized by low $\mathrm{pH}$, low organic carbon and low exchangeable cations.

Table 1: Chemical Properties of Soil and Poultry Manure used for the study before the experiment

\begin{tabular}{llc}
\hline Properties & Soil & Poultry manure \\
\hline $\mathrm{pH}\left(\mathrm{H}_{2} \mathrm{O}\right)$ & 5.16 & 7.60 \\
$\mathrm{Mg}^{+2} \mathrm{cmol} / \mathrm{kg}$ & 0.27 & 1.90 \\
$\mathrm{Ca}^{+2} \mathrm{cmol} / \mathrm{kg}$ & 0.61 & 6.85 \\
$\mathrm{~K}^{+} \mathrm{cmol} / \mathrm{kg}$ & 3.15 & 0.60 \\
$\mathrm{Na}^{+} \mathrm{cmol} / \mathrm{kg}$ & 0.84 & 0.30 \\
$\mathrm{Av} . \mathrm{P} \mathrm{mg} / \mathrm{kg}$ & 3.04 & 1.60 \\
$\% \mathrm{~N}$ & 0.09 & 1.72 \\
$\%$ O.M & 2.31 & 54.64 \\
$\%$ O.C & 1.34 & 27.86 \\
$\mathrm{C}: \mathrm{N}$ ratio & $14.9: 1$ & $16: 1$ \\
$\%$ Sand & 85.20 & - \\
$\%$ Silt & 11.70 & - \\
$\%$ Clay & 3.10 & - \\
Textural class & SL & -
\end{tabular}

SL = Sandy loam

Application of poultry manure improved soil nutrient status of the soil after harvest (Fiollet et al., 1995; Hsich and Hsu, 1993 and Jinadasa et al., 1997). Most of the cassava cuttings sprouted within ten (10) days (Table 4). Number of sprouts (Table 4) increased from 2.83 in cassava cuttings spaced $1.0 \mathrm{~m} \times 1.0 \mathrm{~m}$ without manure to 4.44 in cassava cuttings spaced $1.0 \mathrm{~m}$ $\mathrm{x} 1.0 \mathrm{~m}$ and amended with 4tons/ha at 6 months after planting (MAP). Number of aborted sprouts (Table 4) increased as the months went by. 
Table 2: Effect of plant density and poultry manure rates on cassava stem yields and yield components at 6 MAP

\begin{tabular}{llcc}
$\begin{array}{l}\text { Poultry } \\
\text { Manure }\end{array}$ & $\begin{array}{c}\text { Spacing } \\
(\mathrm{m})\end{array}$ & $\begin{array}{c}\text { Stem } \\
\text { weight }\end{array}$ & $\begin{array}{c}\text { Number of } \\
\text { stem } \\
\text { bundles } \\
\text { /ha }\end{array}$ \\
t/ha & & kg/plot & ha \\
\hline & $1.0 \times 1.0$ & 0.19 & 1,000 \\
& $1.0 \times 0.5$ & 0.15 & 1,875 \\
Mean & $1.0 \times 0.25$ & 0.13 & 5,625 \\
& & 0.16 & 2,833 \\
2 & $1.0 \times 1.0$ & 0.21 & 1,250 \\
& $1.0 \times 0.5$ & 0.18 & 2,500 \\
Mean & $1.0 \times 0.25$ & 0.16 & 7,500 \\
& & 0.18 & 3,750 \\
4 & $1.0 \times 1.0$ & 0.46 & 1,500 \\
& $1.0 \times 0.5$ & 0.23 & 5,000 \\
Mean & $1.0 \times 0.25$ & 0.13 & 8,750 \\
& & 0.27 & 5,083 \\
LSD(0.05) & 0.08 & 630
\end{tabular}

This could be attributed to depletion of food reserve in the cassava stem cuttings which resulted in the death of the sprouts whose roots where above the soil level since they cannot absorb water and nutrients for photosynthesis. NR 8082 had sparse branching (Table 4). This could be attributed to genetic factors inherent in the cassava cultivar (Janick, 1979 and Nweke et al., 1992). Number of leaves (Table 5) was 7.90 and 15.80 in cassava spaced 1.0m $\mathrm{x} 0.25 \mathrm{~m}$ without manure and increased to 10.35 and 39.53 in cassava spaced $1.0 \mathrm{~m} \times 1.0 \mathrm{~m}$ and amended with 4 tons/ha at 3 and 6 MAP respectively. The difference in number of leaves could be attributed to the nitrogen content of the poultry manure which is responsible for vigorous vegetative growth in plant (Cooke, 1982) and equidistant nature of plant spacing which allowed for vigorous leaf development in low density cassava. Cassava stems were tall (Table 5) in high density cassava amended with 4 tons/ha. This could be attributed to intraspecific competition for light among the cassava plants with subsequent elongation to avoid shading by cassava plants as reported by Simwambana et al. (1994). Application of poultry manure boost cassava growth (Alasiri and Ogunkeyede, 1997; Hussein, 1998). 
Table 3: The post physicochemical properties of the experimental soil

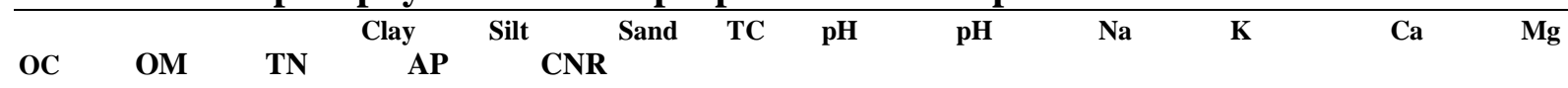

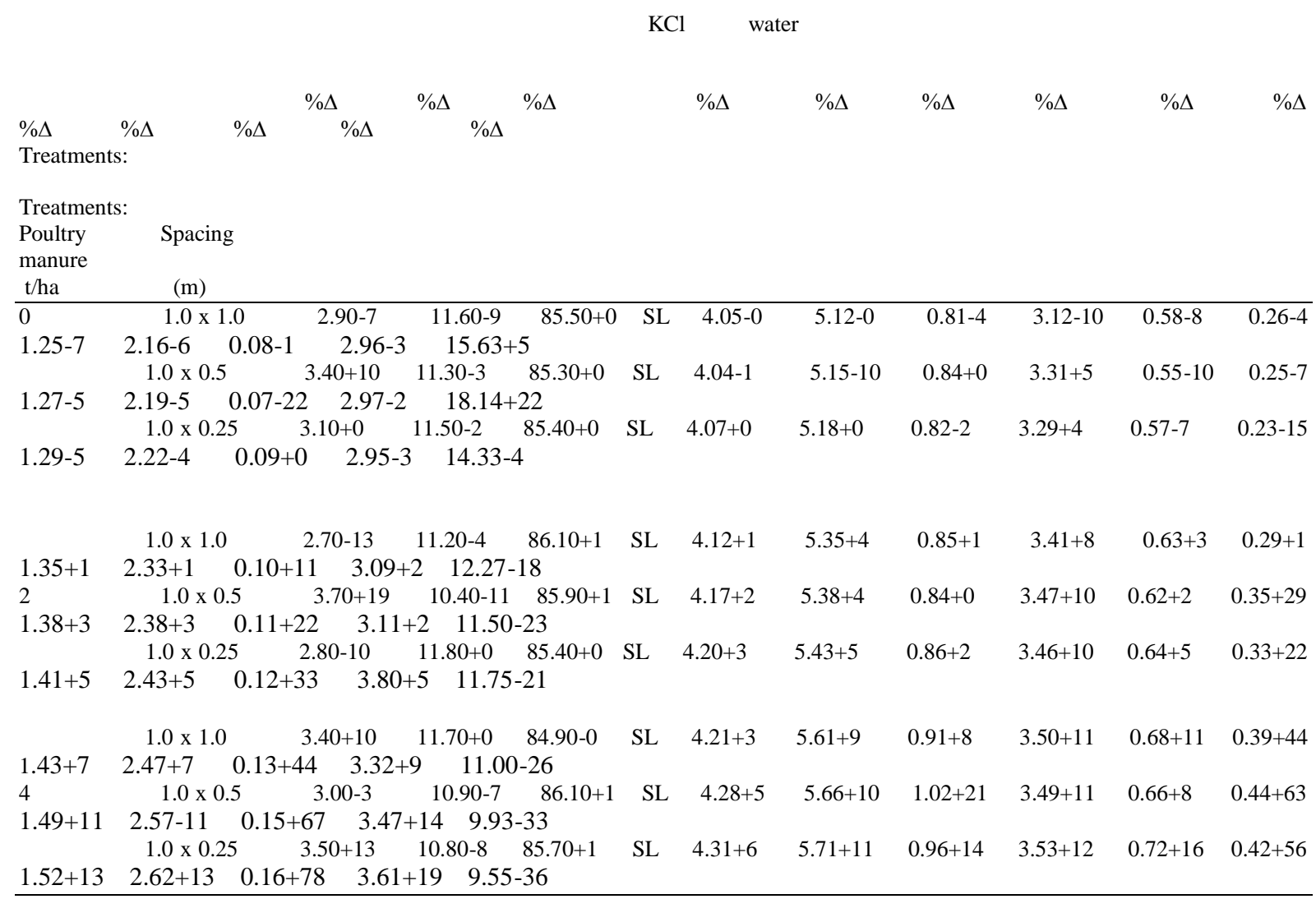

Note: $\mathrm{TEB}=$ Total exchangeable bases, TEA $=$ Total exchangeable acidity, ECEC $=$ Effective cation exchange capacity, $\mathrm{BS}=$ Base saturation

$\mathrm{OC}=$ Organic carbon, $\mathrm{OM}=$ Organic matter, $\mathrm{TN}=$ Total nitrogen, $\mathrm{AP}=$ Available phosphorus, $\mathrm{CNR}=$ Carbon-Nitrogen ratio, $-=$ decrease

$+=$ Increase, $\mathrm{TC}=$ Textural class, $\mathrm{SL}=$ Sandy loamy soil

Table 4: The effect of plant density and poultry manure rates on days to $50 \%$ sprouting, number of sprouts, number of aborted sprouts, number and length of branches at 1,3 , and 6 MAP.

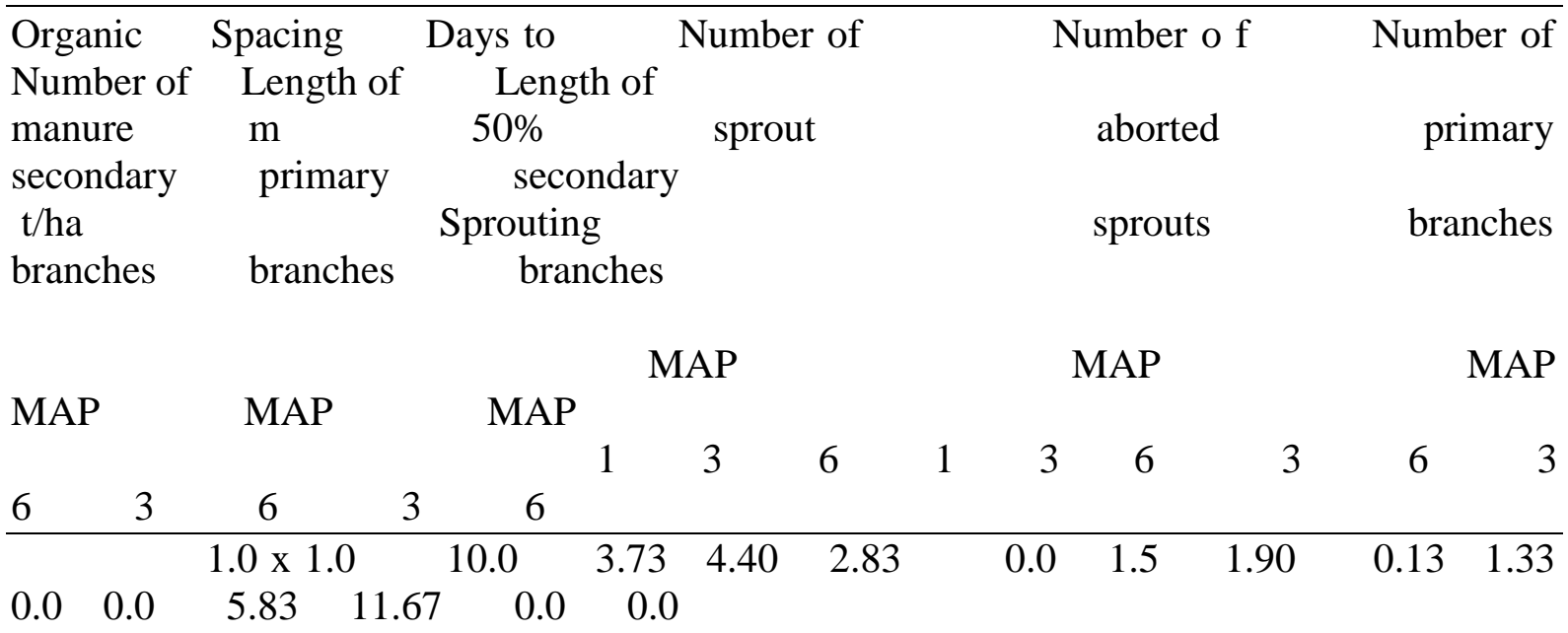


Journal of Agriculture and Social Research (JASR) VOL. 10, No. 2, 2010

\begin{tabular}{|c|c|c|c|c|c|c|c|c|c|c|c|c|}
\hline \multirow{3}{*}{0.0} & 0 & $1.0 \times 0$. & & 12.0 & 4.53 & 4.25 & 3.93 & 0.0 & 1.28 & 1.60 & 0.53 & 1.50 \\
\hline & 0.0 & 10.26 & 24.00 & 0.0 & 0.0 & & & & & & & \\
\hline & & $1.0 \times 0.2$ & & 11.0 & $5.07 \quad 3$ & 3.25 & 3.64 & 0.0 & 2.72 & 2.42 & 0.27 & 2.17 \\
\hline 0.0 & 0.6 & 15.03 & 33.37 & $\begin{array}{ll}7 & 0.0\end{array}$ & 8.0 & & & & & & & \\
\hline & Mean & & & 11.0 & 4.44 & 3.97 & 3.47 & 0.0 & 1.85 & 1.97 & 0.31 & 1.67 \\
\hline 0.0 & 0.2 & 10.37 & 23.01 & 0.0 & 2.67 & & & & & & & \\
\hline 1.0 & x 1.0 & & & 11.0 & 3.60 & 4.08 & 3.67 & 0.0 & 0.93 & 1.07 & 0.13 & 0.67 \\
\hline . & 0.0 & 7.95 & 18.33 & 0.0 & 0.0 & & & & & & & \\
\hline & 2 & $1.0 \times 0$. & & 10.0 & 4.00 & 3.75 & 3.78 & 0.0 & 1.83 & 1.22 & 0.13 & 2.00 \\
\hline 0.0 & 0.0 & 9.32 & 19.50 & 0.0 & 0.0 & & & & & & & \\
\hline & & $1.0 \times 0.2$ & $.25 \quad 1$ & 11.0 & 4.80 & 4.20 & 3.65 & 0.0 & 1.60 & 2.15 & 0.13 & 1.44 \\
\hline 0.0 & 0.0 & 8.10 & 18.39 & 0.0 & 0.0 & & & & & & & \\
\hline & Mean & & & 0.69 & 4.134 .01 & 3.7 & 0.0 & 1.45 & 1.48 & 0.13 & 1.37 & 0.0 \\
\hline 0.0 & $8.4 C$ & 18.39 & & 0.0 & & & & & & & & \\
\hline & & $1.0 \times 1$. & .0 & 10.0 & 4.88 & 4.87 & 4.44 & 0.0 & 1.02 & 1.44 & 0.53 & 1.33 \\
\hline 0.0 & 1.00 & 17.24 & 33.03 & $\begin{array}{ll}3 & 0.0\end{array}$ & 0.0 & & & & & & & \\
\hline & 4 & $1.0 \times 0$ & 0.5 & 10.0 & 4.13 & 3.15 & 3.00 & 0.0 & 1.98 & 2.13 & 0.13 & 1.33 \\
\hline 0.0 & 1.00 & 14.223 & 31.33 & 0.0 & 8.33 & & & & & & & \\
\hline & & $1.0 \times 0$ & .251 & 12.0 & 5.00 & 3.86 & 3.60 & 0.0 & 2.13 & 2.40 & 0.50 & 2.78 \\
\hline & 1.33 & 20.66 & 41.89 & 0.0 & 7.67 & & & & & & & \\
\hline & Mean & & & 10.67 & 4.67 & 3.90 & 3.68 & 0.0 & 1.75 & 1.99 & 0.39 & 1.81 \\
\hline 0.0 & 0.78 & $17.37 \quad 3$ & 35.42 & 0.0 & 5.33 & & & & & & & \\
\hline
\end{tabular}

$\begin{array}{llllllllll}\text { LSD }(0.05) & \text { NS } & \text { NS } & \text { NS } & \text { NS } & \text { NS } & \text { NS } & \text { NS } & 0.24 & \text { NS }\end{array}$ NS NS NS NS NS NS 
Journal of Agriculture and Social Research (JASR) VOL. 10, No. 2, 2010

Table 5: Effect of plant density and poultry manure rates on growth parameters at 3 and 6 MAP.

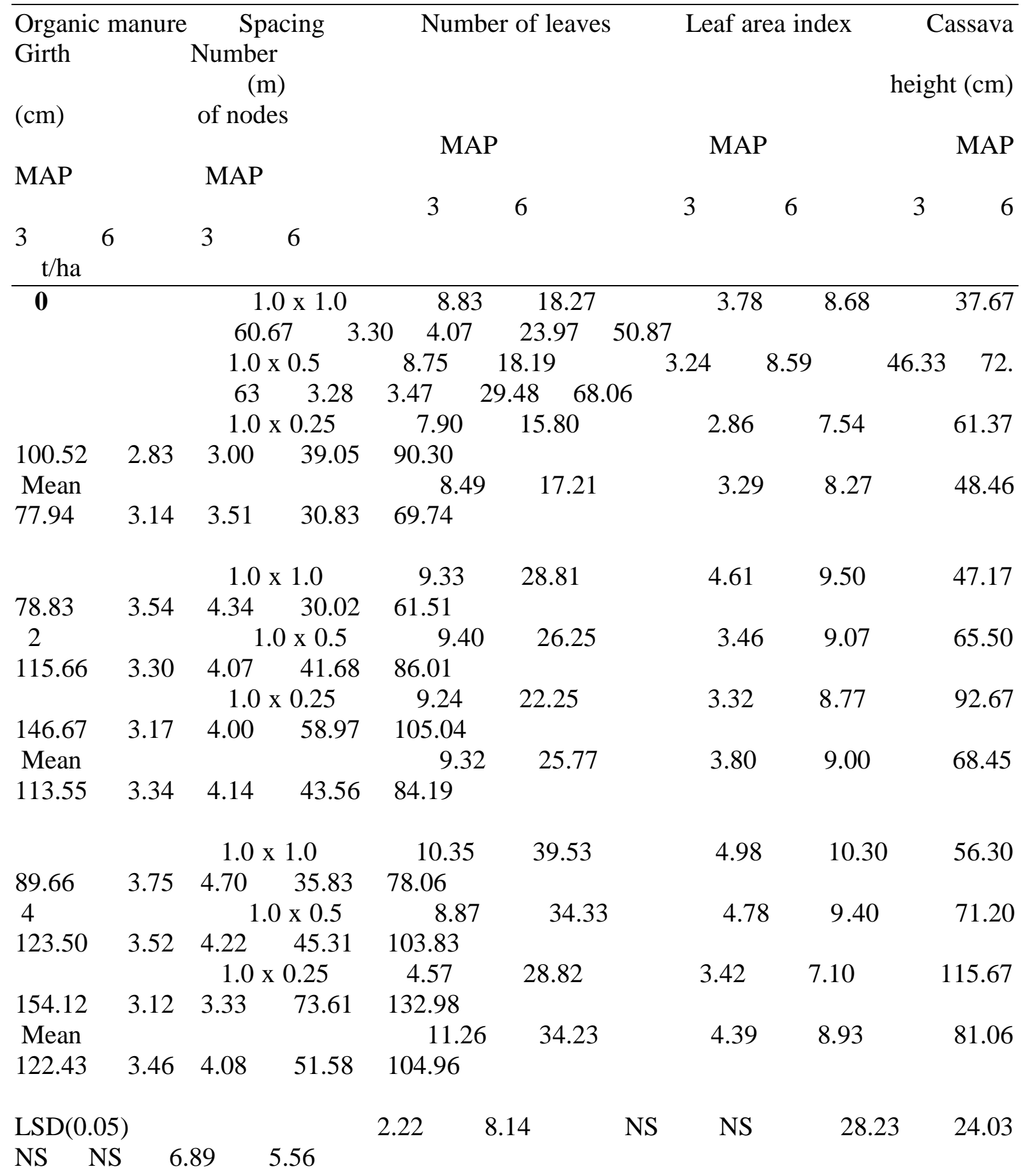

Table 6: The regenerative cassava propagule vigour at 1 MAP

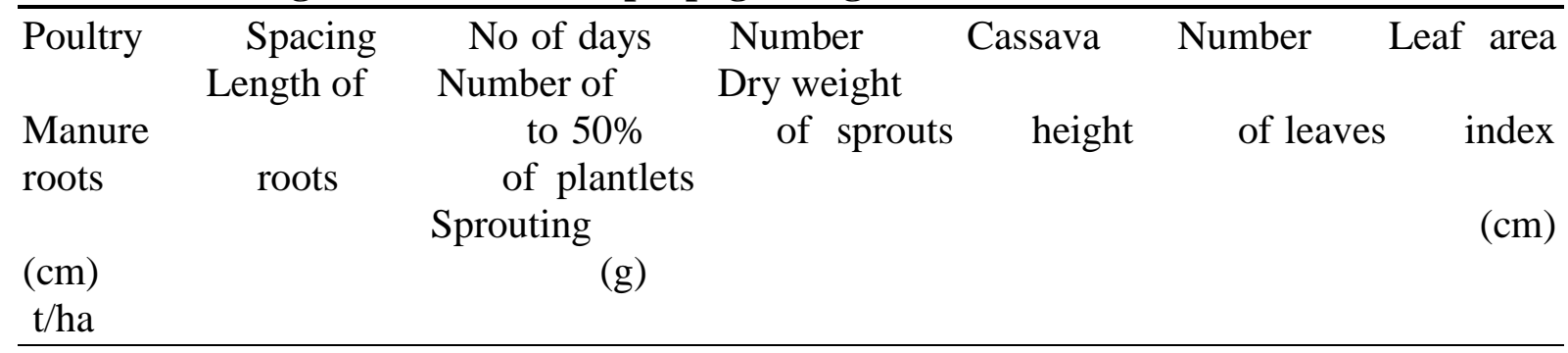




\begin{tabular}{|c|c|c|c|c|c|c|}
\hline & $1.0 \times 1.0$ & 7.00 & 3.40 & 7.08 & 8.33 & 1.73 \\
\hline & 21.10 & 17.40 & 7.07 & & & \\
\hline 0 & $1.0 \times 0.5$ & 9.00 & 3.33 & 6.53 & 7.93 & 1.71 \\
\hline 22.47 & 18.33 & 6.57 & & & & \\
\hline & $1.0 \times 0.25$ & 10.00 & 3.13 & 6.63 & 7.61 & 1.61 \\
\hline 20.80 & 14.13 & 4.16 & & & & \\
\hline Mean & & 8.67 & 3.29 & 6.75 & 7.96 & 1.68 \\
\hline 21.46 & 16.62 & 5.93 & & & & \\
\hline & $1.0 \times 1.0$ & 9.00 & 4.13 & 7.01 & 9.20 & 1.76 \\
\hline 22.47 & 23.33 & 5.37 & & & & \\
\hline 2 & $1.0 \times 0.5$ & 8.00 & 3.90 & 8.77 & 8.23 & 2.27 \\
\hline 22.40 & 21.90 & 4.38 & & & & \\
\hline & $1.0 \times 0.25$ & 10.00 & 3.20 & 8.17 & 8.13 & 1.86 \\
\hline 21.00 & 20.07 & 5.69 & & & & \\
\hline Mean & & 9.00 & 3.74 & 7.98 & 8.52 & 1.96 \\
\hline 21.96 & 21.77 & 5.15 & & & & \\
\hline & $1.0 \times 1.0$ & 7.00 & 2.70 & 8.84 & 9.40 & 2.35 \\
\hline 23.70 & 25.30 & 8.79 & & & & \\
\hline 4 & $1.0 \times 0.5$ & 9.00 & 2.00 & 8.02 & 8.60 & 2.00 \\
\hline 22.00 & 19.30 & 5.81 & & & & \\
\hline & $1.0 \times 0.25$ & 10.00 & 2.53 & 6.89 & 7.73 & 1.81 \\
\hline 21.20 & 17.60 & 3.99 & & & & \\
\hline Mean & & 8.67 & 2.41 & 7.92 & 8.58 & 2.05 \\
\hline 22.30 & 20.73 & 6.20 & & & & \\
\hline $\operatorname{LSD}(0.05)$ & & NS & NS & NS & NS & NS \\
\hline NS & NS & NS & & & & \\
\hline
\end{tabular}

Number of nodes (Table 5) was high in tall cassava. This is because as the cassava elongates, the nodes continues to develop on the stems. Stem weight (Table 8) was $0.46 \mathrm{~kg} / \mathrm{plot}$ in cassava spaced $1.0 \mathrm{~m} \times 1.0 \mathrm{~m}$ and amended with 4 tons/ha of poultry manure. High stem weight could be attributed to reduction of intraspecific competition among the cassava plants. Donald (1958) reported reduction of stalk strength and weight in maize as a result intraspecific competition. In addition, poultry manure supplied soil nutrient elements necessary for plant growth (Alasiri and Ogunkeyede, 1997; Hussein, 1998). Number of stem bundles was high in high density cassava amended with 4 tons/ha of poultry manure. This corroborates the works of Dahniya and Kallon (1984) and Cock et al. (1977) who independently reported high stem bundles in density cassava. Regenerative cassava propagules (Tables 6) had good field establishment vigour at 1 MAP (Otoo, 1996; Dahniya and Kallon, 1984).

\section{CONCLUSION}

This research work revealed changes in the physicochemical properties of the soil as a result of addition of poultry manure which subsequently increased cassava stem yield in the amended plots. Additionally, high density increased stem yield. The stems cuttings had good establishment vigour in the field at $1 \mathrm{MAP}$ and therefore, can be cut and supplied to the farmers at $6 \mathrm{MAP}$ in order to meet the demand for it in the next cropping season. 


\section{Acknowledgments}

The guidance and assistance of Prof. J.C. Obiefuna and Dr. I.I. Ibeawuchi during the conduct and writing of this research work is appreciated. The same gratitude goes to all the staff of Crop Science and Technology, Federal University of Technology, Owerri for their constructive criticism and contributions.

\section{REFERENCES}

Alasiri, K. O. and Ogunkeyede, O.O. (1997): Effect of poultry manure on seed yield of okra. Programme of activities and abstract of papers presented at $24^{\text {th }}$ of Nigeria December 7-11, Abubakar Tafawa Balewa University, Bauchi Nigeria p17.

Akoroda, M.O., Aribisala, O.S., Dixon, A.G.O., Ilona, P., Yomeni, M.O.,Okechukwu, R.U., Ogbe, F., Sanni, L.O., Lemchi, J., Ezedinma, C.,Okoro, E., Tarwali, G., Patino, M., Mkumbira, J. and Semakula, G. (2005): Cassava stems multiplication as agroenterprise in Nigeria. In: Training for seed and quality control officers of ADP and RTEP-MU. Ijebu-Ife, 23-25, May 2005.

Bhojwani, S. S.; M. K. Razdan 1996. Plant tissue culture: theory and practice, Revised edition Elsevier, 767 pp. ISBN-10=0444816232

Bremner, J.M. (1996): Nitrogen Total. In: Sparks, D.L. (ed.). Methods of Soil Analysis. Part 3, chemical method. $2^{\text {nd }}$ edition, SSSA Book Series No.5, SSSA, Madison, W.I., Pp. 1085-1121.

Cock, J.H. (1985): Rapid propagation techniques for cassava. In: Cock J.H., Reyes, J.A. (eds). Cassava: Research, production and utilization. Centro International de Agricultre Tropical, Cali, Colombia. 747p.

Cock, J.H; Wholey, D. and Gintierrez De las Casa o. (1977): Effect if spacing on cassava (Manihot esculenta). Experimental Agriculture 13: 289-299.

Cooke, G.W. (1982): Fertilizing for maximum yield. Granada Publishing Ltd ELBC edition $465 \mathrm{p}$.

Dahniya, N.T. and Kallon, S.N. (1984): Rapid multiplication of cassava by direct planting. IDRC, Ottawa, ON, CA. International Society for Tropical Root Crops. African Branch, Triennial Symposium, 2d, 14-19, Aug. 1983, Douala, CM In ARCHIV 57399.

Donald, C.M. (1958): Interaction of competition for light and for nutrients. Aust. J. Agr. Res. 9:421-435.

Earrnet,(2000):http://www.asareca.org/earrnet/multi_distribution.htm

Folliet, R.H., L.S. Murphy and R.L. Donahue (1995): Fertilizers and Soil amendments. Prentice Hill Inc.Englewood cliffs, U.S.A. pp. 250.

E. F. George, M. A. Hall, and G.-J. De Klerk (eds) 2008. Plant propagation by tissue culture. Volume 1. The background. 3rd edition Springer, Dordrecht, 501 pp. ISBN-13=978-14020-5004-6

Giller, K.E., G. Cardisch, C. Ehaliotis, E, Adama, W.D. Sakala and P.I. Mafongoya (1997): Building soil Nitrogen capital in Africa. Soil Science 164: 671-682.

Hendershot, W.H.; Lalande, H. and Duquette, M. (1993): Soil reaction and exchangeable acidity. In: Carter, M.R. (ed.). Soil sampling and methods of soil analysis, Canadian Soc. Soil Sci., Lewis Publishers, London, Pp141-145.

Hsich, C. F. and Hsu K.N. (1993): An experiment on the organic farming of sweet corn and vegetable soy beans. Bull Taichung district Agric.Improvement sta. No. 39: 29-39.

Hussein, T.O. (1998): Effect of poultry manure on the growth of tomato. Proceedings, $15^{\text {th }}$ Annual Conference HORTSON, April 8-11. NIHORT Ibadan Nigeria p45.

Janick, J. (1979): Horticulture science. W.H. Free man and Company, Sam Francis Co. Pp.608. 


\section{Journal of Agriculture and Social Research (JASR) VOL. 10, No. 2, 2010}

Jinadasa,K.B., P.N. Milham, C.A. Hawkins, P.S. Comish, P.A. Williams, C. J. kaldo, and J.P. Conroy (1997): Survey of cadmium levels in vegetables and soils of greater Sydney. Australia. Journal of Enviromental quality 26; 924-933.

Mayhew, S. and A., Penny (1988): Macmillian Tropical and Subtropical Foods. Macmillian Publishers Ltd London and Basingstoke Pp. 6-10.

Nelson, D.W. and Sommers, L.E. (1982): Total carbon, organic carbon and organic matter. In Page, A.L; Miller, R.H. and Keeney, D.R. (eds). Methods of soil analysis, part 2 Am. Soc. Agron., Madison WI. Pp. 539-579.

Nweke, F.I. (1992): Cassava: A cash crop in Africa. COSCA working paper No.14 Ibadan, Nigeria. International Institute of Tropical Agriculture IITA.

Nweke, F.I., S.K., Hahn and B.O. Ugwu (1992): Circumstances of rapid spread of cultivation of improved cassava varieties in Nigeria. Journal for farming systems research Extension 4(3): 93-119.

Nwosu, A.C. and Adeniyi, E.O. (1980): Imo State. A survey of resources for development. NISER Ibadan 310pp.

Ohiri, A.C. and A.O., Ano (1985): Soil Physical and Chemical characterization of Southeatern States of Nigeria. National Root Crops Research Institute Umudike, Nigeria.

Olsen, S.R. and Sommers, L.E. (1990):Phosphorus In: Page, A.L. (ed.). Methods of Soil Analysis. Parts 2, Agron. Monogr. No. 9 Madison, WI. Pp 403-431.

Onweremadu, E.U.; Opara, C.C; Nkwopara, U; Duruigbo, C.I. and Ibeawuchi,I.I. (2006): Yield response of a Cowpea variety on ground seashells on Isohyperthermic Arenic Kandiudult of Owerri, Southeastern Nigeria. Int. J. Soil Sci., 3:251-257.

Orajaka, S.O. (1975): Geology. In: Nigeria In Maps: Eastern States, G.E.K. Ofomata (ed.). Ethiope Publishing, Benin City, Nigeria. Pp 5-7.

Otoo, J.A. (1996). Rapid multiplication of cassava. IITA Research Guild 51. Training Program, IITA, Ibadan, Nigeria. 22pp.

Pierre, S. (1989): Cassava: The Tropical Agriculturist. CTA Macmillian London and Basingstoke. Pp. 22-64.

Spencer, D., G.H. Peters and D.D. Hedley (1997): Cassava in Africa: Past, present and future prepared for the International Institute of Tropical agriculture. Freetown Sierra Leone: Dunstan Spencer and Associates.

Tian, G.B.T., Kang and T. Brusserd (1994): Mulching effects of plant residue with chemically contrasting composition on maize growth and nutrient accumulation. IITA Res. 9: 7-11.

Simwambana, M.S.C., Ferguson and I.J., Ekanayake (1994): Influence of cultural and environmental factors on reproductive behaviour, growth and and branching habit of 4 cassava genotypes. Aust. J. Agr. Res. 9:221-235.

Ustimenko-Bakumovsky, G.V. (1983): Plant growing in the tropics and subtropics Min. Publishers. Moscow Pp. 28-264.

Wahua, T.A.T. (1999). Applied Statistics for Scientific Studies. Afrilink books Ibadan, pp. 60-85. 